\title{
Essay
}

\section{The Right-Remedy Gap in Constitutional Law}

\author{
John C. Jeffries, Jr. ${ }^{\dagger}$
}

Ever since John Marshall insisted that for every violation of a right, there must be a remedy, ${ }^{1}$ American constitutionalists have decried the rightremedy gap in constitutional law. Everyone agrees that victims of constitutional violations should have effective redress. So when Akhil Amar declares that governments acting unconstitutionally "must in some way undo the violation by ensuring that victims are made whole," 2 he voices a proposition commanding nearly universal assent. At least, as an ideal. When pressed, most of us recognize that the law of remedies is, in the words of Paul Gewirtz, inevitably "a jurisprudence of deficiency, of what is lost between declaring a right and implementing a remedy." ${ }^{3}$ The distance between the ideal and the real means that there will always be some shortfall between the aspirations we call rights and the mechanisms we call remedies.

Recognizing that a right-remedy gap is probably inevitable in constitutional law and is in any event deeply embedded in current doctrine, some scholars have modulated the strict imperative of full remediation.

$\dagger$ Emerson Spies Professor, William L. Matheson \& Roben M. Morgenthau Research Professor, and Acting Dean, University of Virginia School of Law. Thanks go to Akhil Amar. Dick Fallon, Michael Klarman, Daryl Levinson, Dan Meltzer, George Rutherglen. Jim Ryan, Mike Seidman, Bill Stuntz, and participants in workshops at the University of Florida. the University of Kansas, and the University of Virginia for helpful comments on carlier drafts of this essay, and to Alex Chinoy for valuable research assistance.

1. See Marbury v. Madison, 5 U.S. (1 Cranch) 137. 163 (1803) ("The government of the United States has been emphatically termed a government of laws, and not of men. It will certainly cease to deserve this high appellation, if the laws furnish no remedy for the violation of a vested legal right."). Marshall also quoted Blackstone's more familiar formulation: "[I]t is a general and indisputable rule, that where there is a legal right, there is also a legal remedy, by suit or action at law, whenever that right is invaded." 3 WILLIAM BLACKSTONE, COMAIENTARIES *23.

2. Akhil Reed Amar, Of Sovereignty and Federalism, 96 YALE L.J. 1425, 1427 (1987).

3. Paul Gewirtz, Remedies and Resistance, 92 YALE L.J. 585. 587 (1983). 
Richard Fallon and Daniel Meltzer have recast Marbury v. Madison's "apparent promise of effective redress for all constitutional violations" as a "principle, not an ironclad rule," an ideal in practice "not always attained." 4 They rank this ideal below the "more absolute" requirement of "a general structure of constitutional remedies adequate to keep government within the bounds of law."

This systemic reformulation of Chief Justice Marshall's maxim has important advantages over the original. It less plainly contradicts current law and more readily accommodates the familiar idea that Congress may substitute one remedy for another within some generally adequate scheme of constitutional enforcement. ${ }^{6}$ Since no remedial scheme will be optimal for all plaintiffs, legislative power to provide one remedy and withhold another strongly implies that there will be situations where individual victims of constitutional violations do not receive effective redress. ${ }^{7}$ Indeed, it may be that the only constitutionally mandatory, as distinct from normatively desirable, remedial scheme is the right of a target of government prosecution or enforcement to defend against that action on the ground that it violates the superior law of the Constitution. ${ }^{8}$ Even for those

4. Richard H. Fallon, Jr. \& Daniel J. Meltzer, New Law, Non-Retroactivity, and Constitutional Remedies, 104 HARv. L. REV. 1731, 1778 (1991); cf. Louis Michael Seidman, Akhil Amar and the (Premature?) Demise of Criminal Procedure Liberalism, 107 YALE L.J. 2281. 2298 (1998) (book review) (arguing that the aim of constitutional remedies for criminal procedure violations should be "systemic deterrence," not "individual remediation").

5. Fallon \& Meltzer, supra note 4, at 1736.

6. A classic articulation of this idea comes from Walter E. Dellinger, Of Rights and Remedies: The Constitution as a Sword, 85 HARV. L. REV. 1532, 1552-53 (1972) ("[W] [Were the judiciary independently infers remedies directly from constitutional provisions, Congress may legislate an alternative remedial scheme which it considers equally effective in enforcing the Constitution and which the Court, in the process of judicial review, deems an adequate substitute for the displaced remedy."). See also Gene R. Nichol, Bivens, Chilicky, and Constitutional Damages Claims, 75 VA. L. REV. 1117, $1144-45$ (1989) (endorsing congressional power to replace Bivens actions with constitutionally "adequate" alternatives).

7. See Fallon \& Meltzer, supra note 4, at 1736, 1779 n.244. Of course, it is logically possible to recognize legislative power to choose among remedies only if the remedy chosen provides not just generally adequate enforcement but full individual remediation. See, e.g., Amar, supra note 2. at 1490-91 ("A government may immunize itself, even for ultra vires acts, but only if other remedies-for example, strict liability suits against non-judgment-proof individual officers-can guarantee victims full redress."). If limited to remedies that would "guarantee" full redress in every case, legislative "choice" would be mostly meaningless.

8. See Seminole Tribe v. Florida, 517 U.S. 44, 73-74 (1996) (finding the remedy of injunctive relief against state officers under Ex parte Young also subject to congressional withdrawal): United States v. Stanley, 483 U.S. 669, 683-84 (1987) (holding that no Bivens remedy is available for injuries incurred in military service, regardless of whether Congress has provided some other "adequate" remedy); Bivens v. Six Unknown Named Agents of Fed. Bureau of Narcotics, 403 U.S. 388, 407 n.7 (1971) (Harlan, J., concurring) (expressing no view, and interpreting the opinion of the Court to express no view, on congressional authority to discard the damages remedy created in that case). Conventional wisdom regards a damages remedy as constitutionally required by the Just Compensation Clause, see, e.g., Fallon \& Meltzer, supra note 4, at 1778-79. but even that may not be strictly true. Recent scholarship suggests that historically the effect of the Just Compensation Clause was to invalidate legislation that authorized an uncompensated taking, thereby removing an officer defendant's justification of public authority and leaving him subject 
willing to settle for something less, full individual remediation remains the ideal. ${ }^{9}$ Deviations from that ideal are viewed with skepticism and regret. Unredressed constitutional violations may have to be tolerated, but they should not be embraced, approved, or allowed to proliferate. Moreover, full redress for individual victims of constitutional violations is not only desirable in itself; it is also the direct and obvious route to an adequate system of constitutional enforcement. Doctrines that curtail individual redress thus not only deny full remediation to some victims; they also call into question the adequacy of the overall structure of constitutional enforcement. Typically, therefore, constitutional law scholars insist on full individual remediation as a starting principle and strenuously contest exceptions. The result is an attitudinal presumption against any gap between right and remedy in constitutional law.

In today's constitutional landscape, the largest, most lamented, and least defended gap between right and remedy involves money damages. Although 42 U.S.C. $\S 1983$ provides for damages actions against state and local officers who violate constitutional rights, ${ }^{10}$ and Bivens creates a parallel claim against federal defendants, ${ }^{1}$ the promise of monetary compensation for constitutional violations has not been fulfilled. On the contrary, current doctrine sharply curtails damages liability for constitutional violations, chiefly by requiring proof of fault (beyond the mere fact of a constitutional violation) by a government officer. Generally speaking, the kind of fault required is negligence with respect to illegality. ${ }^{12}$ When such fault cannot be proved, damages cannot be had. When damages cannot be had, there will often be no other remedy or at least no other remedy that makes the injured whole. As a result, many victims of constitutional violations get nothing, and many others get redress that is less than complete. In constitutional torts, the right-remedy gap is huge, and the

to various remedies at common law. See Robert Brauneis, The First Constitutional Tort: The Remedial Revolution in Nineteenth-Century State Just Compensation Law, 52 VAND. L. REV. 57. 64-65 (1999).

9. See, e.g., Fallon \& Meltzer, supra note 4, at 1778-79.

10. The statute provides, in perinent par:

Every person who, under color of any statute, ordinance, regulation, custom, or usage. of any State or Territory or the District of Columbia, subjects, or causes to be subjected. any citizen of the United States or other person within the jurisdiction thereof to the deprivation of any rights, privileges, or immunities secured by the Constitution and laws, shall be liable to the party injured in an action at law, suit in equity, or other proper proceeding for redress ....

42 U.S.C. \& 1983 (1994).

11. See Bivens, 403 U.S. at 397.

12. The usual formulation is that qualified immunity protects an officer defendant when a reasonable officer "could have believed" his or her conduct to be lawful. See, e.g. . Hunter v. Bryant, 502 U.S. 224, 228 (1991) (per curiam) (holding that Secret Service agents are immune from damages liability for an unlawful arrest "if a reasonable officer could have believed" in the existence of probable cause). The derivation and content of this standard are examined more fully infra notes 13-29 and accompanying text. 
societal loss in underenforced constitutional norms is correspondingly great.

These deficiencies are so obvious that one must wonder why the courts so steadfastly restrain money damages. The usual answer focuses on the tradeoff between enforcement of constitutional rights and the practical necessities of government. It is a familiar (though not always well understood) argument that qualified immunity enables government officers to go about their business without debilitating fear of damages liability. The threat of overdeterrence-more accurately, the threat of unintended deterrence of socially desirable activity-justifies limiting damage recoveries in order to protect the legitimate but nonconstitutional interests at stake in the business of government. This is an important argument, famously articulated by Peter Schuck, ${ }^{13}$ which I have tried elsewhere to redirect and refine,${ }^{14}$ but it is not the point of this Essay. Rather, my purpose here is to suggest that the limitation on money damages for constitutional violations has constitutional benefits as well as costs. The values served by the doctrine of qualified immunity are not limited to easing the ordinary, workaday business of government, but extend as well to the domain of constitutional rights. Indeed, I hope to show that the curtailment of damages liability for constitutional violations has deep structural advantages for American constitutionalism.

Put simply, limiting money damages for constitutional violations fosters the development of constitutional law. Most obviously, the rightremedy gap in constitutional torts facilitates constitutional change by reducing the costs of innovation. The growth and development of American constitutionalism are thereby enhanced. More importantly, the fault-based regime for damages liability biases constitutional remedies in favor of the future. Limitations on damages, together with modern expansions in injunctive relief, shift constitutional adjudication from reparation toward reform. Resources are directed away from cash compensation for past injury and toward the prevention of future harm. The result is a rolling redistribution of wealth from older to younger, as the societal investment in constitutional law is channeled toward future progress and away from backward-looking relief.

The argument proceeds in three stages. Part I summarizes existing law. Although beset by exceptions, indirections, and complications, current doctrine coalesces around the concept of fault. The need to establish an officer's fault is the chief limitation on damages liability for constitutional violations and the main source of the right-remedy gap in constitutional

13. See Peter H. SCHUCK, Suing Government: Cittzen Remedies for Official WRONGS 59-81 (1983).

14. See John C. Jeffries, Jr., In Praise of the Eleventh Amendment and Section 1983, 84 VA. L. REV. 47, $72-78$ (1998). 
torts. Part II develops the argument that the requirement of fault facilitates constitutional innovation and favors the future. In essence, the limitation on money damages shifts societal resources away from reparation for past harms and toward investment in future welfare, continually redistributing societal resources from older to younger citizens. Part III adds some concluding comments on injunctive relief. The combination of damages that stop short of full remediation and injunctions that go beyond prohibiting constitutional violations builds into the deep structure of constitutional remedies a healthy bias toward the forward-looking.

Two caveats will clarify what I do and do not mean. First, I do not believe that the right-remedy gap in constitutional law is in itself a good thing. Injury is always to be regretted, especially when unredressed, and it may be (though it is not obvious to me) that, within the universe of unredressed injuries, those that result from violations of constitutional rights are worst of all. Moreover, underdeterrence of constitutional violations is a cost and must be counted as such, even if one believes (as I do) that the cost might be justified by competing concerns. My point is not that the curtailment of damage recoveries for constitutional violations is intrinsically desirable, but only that it has important (and overlooked) advantages, which may or may not be thought offsetting. In other words, I hope to convince the reader that the gap between right and remedy in constitutional torts is not an unmitigated disaster but a double-edged sword.

Second, that I defend the requirement of fault as the mediating doctrine between right and remedy in constitutional torts does not mean that I endorse the precise contours of existing law. On the contrary, my assessment is that current protections against damages liability for unconstitutional conduct are extravagant. In my view, the Supreme Court is requiring too much fault as a condition of constitutional tort liability. This Essay does not dwell on the difficult (and highly context-specific) questions of how much fault, and exactly what kind of fault, should be required. My purpose here is to address the antecedent and foundational question of whether fault should be required at all. If not, then at least from a normative perspective, the precise content of the qualified immunity defense need not be debated further. If, however, the essential rationales for conditioning damages liability on proof of fault are accepted and understood, the groundwork will have been laid for determining the appropriate scope of qualified immunity for various rights and contexts.

\section{THE CENTRALITY OF FAULT}

The rules on damages actions for constitutional violations appear to be a perfect jumble. Some governmental defendants have absolute immunity, others face absolute liability, and most fall somewhere in between. The 
Supreme Court explains the contradictions by resorting to doctrinal formalism and bogus history, often without even a passing attempt at functional justification. No one would suggest that these liability rules cohere, but they do tend to coalesce, to a greater extent than is commonly recognized, around a requirement of fault. ${ }^{15}$

Under the Eleventh Amendment and 42 U.S.C. $\S 1983$, states and state agencies have absolute immunity from damages liability for constitutional violations. ${ }^{16}$ The same is true of state and local officers sued for legislative, judicial, and certain prosecutorial acts. ${ }^{17}$ At the other extreme are local governments, which are strictly liable for unconstitutional acts done pursuant to official policy or custom. ${ }^{18}$ In between are the vast bulk of federal, state, and local officers, who can be held liable under $\S 1983$ or Bivens, but not for conduct that a reasonable officer could have believed to be lawful. ${ }^{19}$

In practice, both absolute immunity and absolute liability are less important than they first appear. The apparently categorical bar against state liability for constitutional violations can be evaded by suing state officers. ${ }^{20}$ For reasons of pragmatic calculation rather than federal coercion, states and localities routinely defend their employees against damage actions and indemnify them against adverse judgments. ${ }^{21}$ Thus, the nominal immunity of states under the Eleventh Amendment and $\S 1983$ typically translates to

15. The description that follows is drawn from Jeffries, supra note 14 , which documents the role of fault in considerably more detail.

16. See Will v. Michigan Dep't of State Police, 491 U.S. 58, 64-66 (1989) (reading "person" in $\$ 1983$ not to include states or state agencies); Hans v. Louisiana. 134 U.S. 1, 15-16 (1890) (reading state sovereign immunity into the Eleventh Amendment).

17. See Imbler v. Pachtman, 424 U.S. 409, 430 (1976) (finding absolute immunity for prosecutorial acts to be "intimately associated with the judicial phase of the criminal process"); Pierson v. Ray, 386 U.S. 547, 553-55 (1967) (granting absolute immunity for judicial acts); Tenney v. Brandhove, 341 U.S. 367, 376 (1951) (granting absolute immunity for legislative acts).

18. See Owen v. City of Independence, 445 U.S. 622, 638 (1980) (holding that localities have no defense of qualified immunity); Monell v. New York City Dep't of Social Servs., 436 U.S. $658,690-91$ (1978) (holding that localities can be held liable under $\$ 1983$ for official policy).

19. See Anderson v. Creighton, 483 U.S. 635, 638, 641 (1987) (holding that qualified immunity extends to actions "a reasonable officer could have believed . . . to be lawful"); Harlow v. Fitzgerald, 457 U.S. 800,818 (1982) (holding that executive officers are generally shielded from liability so long as their conduct does not violate "clearly established . . . rights of which a reasonable person would have known").

20. Courts almost never disallow properly pleaded constitutional claims against state officers on the ground that they are "really" against the state and therefore barred by the Eleventh Amendment. This conclusion and the research that supports it are explained in Jeffries, supra note 14, at 59-68. Suits for violations of federal statutes, however, are treated somewhat differently.

21. Unfortunately, the incidence of defense and indemnification in officer suits is not well described in the literature. Governmental willingness to stand behind officer defendants does not extend to cases of flagrant bad faith (of the sort that would prompt criminal prosecution), but such defense is otherwise routine. See id. at 49-51 (concluding that "[s]o far as can be assessed," defense and reimbursement of officer defendants occur "not occasionally and haphazardly but pervasively and dependably"). 
(indirect) state liability via an officer suit, provided that the officer's qualified immunity can be overcome. ${ }^{22}$ Liability hinges on proof of fault.

At the other end of the spectrum is the strict liability of municipalities and other local governments for acts done pursuant to official policy or custom. Recent Supreme Court decisions have construed that requirement so stringently that access to strict liability is quite rare. ${ }^{23}$ Moreover, in "failure-to-train" cases, the Court has explicitly reintroduced fault by requiring "deliberate indifference" to violations of constitutional rights. ${ }^{24}$ Indeed, the Court's most recent pronouncement suggests that a majority may be ready to abandon strict liability altogether and return to requiring fault in all cases of municipal liability. ${ }^{25}$ However this situation may develop, at present the availability of strict liability for local government violations of constitutional rights is extremely narrow. In most cases, plaintiffs must sue local officers, who, like their state counterparts, are not strictly liable. Thus, despite the occasional reality of absolute immunity and absolute liability, in the overwhelming majority of constitutional tort cases, damages liability depends on fault.

The doctrinal home of fault in constitutional torts is the defense of qualified immunity. Originally described as requiring a reasonable and good faith belief in the legality of the act in question, ${ }^{26}$ qualified immunity

22. A similar substitution of defendants can result in damages liability for unconstitutional legislation. The legislator who passes the law may have absolute immunity, but the executive officer who enforces it does not. Usually, the opportunity to sue an enforeement official suffices to establish liability for unconstitutional legislation, again provided that qualified immunity can be overcome. See generally Ann Woolhandler, Patterns of Official Immunity and Accountability, 37 CASE W. RES. L. REV. 396, 400-06 (1987) (describing executive accountability as consistent with, and perhaps a necessity of, legislative and judicial immunity). The Supreme Court, however. has upheld absolute immunity for legislative acts even in the unusual case where there is no alternative defendant. See Bogan v. Scott-Harris, 523 U.S. 44, 54-56 (1998) (holding that local legislators are absolutely immune from suit for retaliatory firing where they defunded a city department of which the plaintiff was the sole employee). No such substitution of defendants mitigates absolute immunity for judicial acts or for those prosecutorial acts "intimately associated with the judicial phase of the criminal process." Imbler, 424 U.S. al 430 . In these contexts, the functional justification for absolute immunity, if there is one, must be that misconduct by judges and by prosecutors in the course of trials ordinarily can be corrected at trial or on appeal without frequent necessity for resort to actions for money damages. See Ronald A. Cass, Damage Suits Against Public Officers, 129 U. PA. L. REV. 1110, 1146-47, 1150 (1981): Woolhandler, supra, at 411. Plainly, however, there will be some situations in which no alternative remedy exists and absolute immunity is just that.

23. See, e.g., City of St. Louis v. Praprotnik, 485 U.S. 112, 124-27 (1988) (plurality opinion).

24. See City of Canton v. Harris, 489 U.S. 378, 388-89 (1989).

25. See Board of County Comm'rs v. Brown, 520 U.S. 397, 405-06 (1997). In Brown, the majority repeatedly stressed "fault" or "culpability" as a prerequisite to governmental liability, even though this was precisely what the Coun had said in Ow'en v. Ciry of Independence. 445 U.S. 622,638 (1980), was not required. The Court in Brown purported to apply Ow'en but did so only by misdescribing its facts and holding. Where this leaves the strict liability rule of Owen is anyone's guess. As I have noted elsewhere, “"To say that Brown is not a model of clarity would be a model of understatement." Jeffries, supra note 14 , at 58 n.40.

26. See Scheuer v. Rhodes, 416 U.S. 232, 247-48 (1974) ("It is the existence of reasonable grounds for the belief formed at the time and in light of all the circumstances, coupled with good- 
has been reformulated as a purely objective inquiry. ${ }^{27}$ Today, the question is whether a reasonable officer could have believed the act to be lawful. ${ }^{28}$ The reasonableness of a mistake as to unconstitutionality depends on the factual circumstances, the clarity and specificity of the constitutional rule, and the knowledge that the defendant could reasonably be expected to have. The interaction of these factors has produced a defense of qualified immunity that is significantly context-dependent. In fact, though not in theory, there is a law of qualified immunity for school officials, mental health officers, law enforcement personnel, etc. ${ }^{29}$ Describing this variegated landscape in detail is beyond the scope of this Essay, but this much can be said with confidence: The defense of qualified immunity shields government officers, and indirectly shields governments themselves, from damages liability for a substantial range of unconstitutional conduct. The right-remedy gap in constitutional tort law is chiefly a function of the requirement of fault.

For that reason, academics have attacked the requirement of fault in constitutional tort law and supported the ready availability of money damages for constitutional violations. Within this general project are several doctrinal threads. Many scholars have argued against importing state sovereign immunity into the Eleventh Amendment and in favor of an alternative reading that would make states suable on federal claims. ${ }^{30}$ Scholars have also criticized the defense of qualified immunity, arguing for strict liability of the officer defendant or the governmental employer. ${ }^{31} \mathrm{~A}$

faith belief, that affords a basis for qualified immunity ...."). The earliest formulation came from Pierson v. Ray, 386 U.S. 547, 557 (1967), in which the Court described the defense, with obvious reference to a claim of unconstitutional arrest, as requiring "good faith and probable cause."

27. See Crawford-El v. Britton, 523 U.S. 574, 588 (1998) (declaring the defendant's subjective intent "simply irrelevant" to the defense of qualified immunity).

28. See, e.g., Hunter v. Bryant, 502 U.S. 224, 228 (1991) (per curiam); Anderson v. Creighton, 483 U.S. 635, 639 (1987).

29. See 2 Sheldon H. NAHMOd, Civil Rights and Civil Liberties Litigation: THe LaW OF SECTION $1983 \S \S 8.09-8.21$ (3d ed. 1991) (analyzing qualified immunity for each of these categories).

30. See, e.g., Amar, supra note 2, at 1473-84; Martha A. Field, The Eleventh Amendment and Other Sovereign Immunity Doctrines (pt. 1), 126 U. PA. L. REV. 515, 538-40 (1978): William A. Fletcher, The Diversity Explanation of the Eleventh Amendment: A Reply to Critics, 56 U. CHI. L. REV. 1261, $1271-75$ (1989); William A. Fletcher, A Historical Interpretation of the Eleventh Amendment: A Narrow Construction of an Affirmative Grant of Jurisdiction Rather than a Prohibition Against Jurisdiction, 35 STAN. L. REV. 1033, 1060-63 (1983); Vicki C. Jackson, The Supreme Court, the Eleventh Amendment, and State Sovereign Immunity, 98 YALE L.J. 1. 39-5I (1988); James E. Pfander, History and State Suability: An "Explanatory" Account of the Eleventh Amendment, 83 CORNELl L. REV. 1269, 1279 (1998); Suzanna Sherry, The Eleventh Amendment and Stare Decisis: Overruling Hans v. Louisiana, 57 U. CHI. L. REV. 1260, 1271-72 (1990).

31. See, e.g., Amar, supra note 2, at 1490-91 (accepting "strict liability suits against nonjudgment-proof individual officers" as an acceptable implementation of the "remedial imperative" of governmental liability); Mark R. Brown, Correlating Municipal Liability and Official Immunity Under Section 1983, 1989 U. ILL. L. REV. 625, 631 (arguing that governmental liability and officer immunity should be inversely correlated to eliminate any gap between right and remedy); Mark R. Brown, The Demise of Constitutional Prospectivity: New Life for Owen?, 79 IOWA L. REV. 273, 311-12 (1994) (concluding that immunity is inappropriate even for violations of newly declared constitutional rights); Harold S. Lewis, Jr. \& Theodore Y. Blumoff. 
more particular version of this argument focuses on the pocket of the strict damages liability in current law-local government liability for unconstitutional acts done pursuant to official policy or custom-and urges expansion of that category. ${ }^{32}$ Though these writings differ in thesis and methodology, they share a common antipathy toward doctrines that deny full remediation in acknowledged cases of constitutional violations. Generally speaking, these articles_and indeed most writings on § 1983aim to close the right-remedy gap in constitutional law.

\section{THE IMPORTANCE OF INNOVATION}

The rhetoric of constitutional law looks to the past. It emphasizes fidelity to precedent, respect for tradition, and acceptance of prior practice. Constitutional argument regularly invokes the intent of the Framers, even when they had none, ${ }^{33}$ and uses a variety of techniques for claiming continuity while embracing innovation. Sometimes the past is described at such a high level of abstraction that the reference has no meaning. ${ }^{34}$

Reshaping Section 1983's Asymmetry, 140 U. PA. L. REv. 755, 756 (1992) (arguing for strict respondeat superior liability, "regardless of the agent's state of mind, status in the entity's hierarchy, or role in the formulation of its policies"); Susanah M. Mead. 42 U.S.C. \$1983 Municipal Liability: The Monell Sketch Becomes a Distorted Picture, 65 N.C. L REv. 517,538 (1987) (arguing for strict respondeat superior liability): Sheldon Nahmod. Constitutional Damages and Corrective Justice: A Different View, 76 VA. L. REv. 997, 1019 (1990) (arguing against qualified immunity and in favor of compensatory damages for all foresceable harm stemming from constitutional violations); Laura Oren, Immenity and Accountability in Civil Rights Litigation: Who Should Pay?, 50 U. PrTT. L. REV. 935, 1000-02 (1989) (cndorsing strict respondeat superior liability); Christina B. Whitman, Government Responsibiliny for Constitutional Torts, 85 MICH. L. REV. 225, 229-30 (1986) (urging enterprise liability for constitutional violations without regard to the fault, or lack thereof, of individual officers).

32. See, e.g., Steven Stein Cushman, Municipal Liability Under $\S$ 1983: Toward a New Definition of Municipal Policymaker, 34 B.C. L. REV. 693, $723-28$ (1993) (sceking a broader definition of policymaking officials).

33. In this category are invocations of the Framers on behalf of the current, and I think plainly ahistorical, interpretation of the Establishment Clause as a federal ban against state support of religion. See, e.g., Engel v. Vitale, 370 U.S. 421, 425-33 (1962) (reviewing the origin and history of the Establishment Clause in suppor of the prohibition against state-sponsored school prayer); Everson v. Board of Educ., 330 U.S. 1, 8-16 (1947) (reviewing the origin and history of the Establishment Clause in support of a "wall of separation" banning state support of religious activities or institutions). Scholars have criticized the reasoning of these cases. See AKHIL REED AMAR, THE BLI OF RIGHTS 33-34 (1998) (concluding that "to apply the clause against a state government is precisely to eliminate its right to choose whether to establish a religion-a right clearly confirmed by the establishment clause itself"); Alfred H. Kelly. Clio and the Courn: An Illicit Love Affair, 1965 SUP. CT. REV. 119, $137-42$ (criticizing the historical basis for Everson. Engel, and similar decisions).

34. I am indebted to my colleague George Ruthergien for suggesting a citation here to Shaffer v. Heitner, 433 U.S. 186 (1977), in which the Cour said that "'[t]raditional notions of fair play and substantial justice' can be as readily offended by the perpetuation of ancient forms that are no longer justified as by the adoption of new procedures that are inconsistent with the basic values of our constintional heritage," id. at 212-in other words. that tradition can be offended by tradition. Cf. Peter Westen, The Empty Idea of Equality, 95 HARV. L. REv. 537, 542 (1982) (suggesting that references to "equality" typically have no meaning). 
Sometimes precise and detailed descriptions of specific past practices are deployed to resolve unrelated questions. ${ }^{35}$ Sometimes the Court finds elaborate instructions in legislative silence, ${ }^{36}$ at other times, the Court ignores a silence that speaks loud and clear. ${ }^{37}$ And sometimes, of course, the Court simply imagines a prior history to suit current needs. ${ }^{38}$

Constitutional law's rhetorical commitment to the past is so strong that it is easy to lose sight of the importance of change. Not too many decades ago, the law governing police practices was state law; federal criminal procedure did not exist. Today, federal criminal procedure is a staple of the law school curriculum and is concerned almost entirely with constitutional law. Explosive growth has also occurred in the First Amendment. Before the 1960s, it would have been hard to sustain a semester's attention on that subject. Today, many law schools offer an advanced course (or two or

35. Among many candidates, my favorite example of this technique is Pulliam v. Allen. 466 U.S. 522 (1984), in which a lengthy review of the evolution of the primacy of the King's Bench among English courts was adduced to show that American judges are not absolutely immune from the award of injunctive relief. After several pages of historical detail, the Court conceded that " [t]he relationship between the King's Bench and its collateral and inferior courts is not precisely paralleled in our system by the relationship between the state and federal courts," $i d$. at 535, but it insisted that the experience on a different question in a different country at a different time and under a vastly different legal system was nonetheless "highly relevant," id. at 536. Of the strong functional reasons for allowing injunctive relief against judges in the narrow and unusual circumstances where no form of appellate review is available, the Court said nothing at all.

36. A good example is the elaborate body of law on official immunities under 42 U.S.C. $\S 1983$ and analogous Bivens-type actions, supposedly springing from the fact that Congress said nothing at all on that subject in the 1871 Civil Rights Act. See, e.g.. Pierson v. Ray, 386 U.S. 547 (1967).

37. This is my perception of Jones v. Alfred H. Mayer Co., 392 U.S. 409 (1968), in which the Supreme Court ruled, on grounds of history, that the Civil Rights Act of 1866 (predecessor to 42 U.S.C. $\$ 1982$ ) proscribed purely private racial discrimination in the sale or lease of real or personal property. See id. at $422-37$. If that were true, one would have thought that the legislators at the time would have noticed and remarked that the statute, thus interpreted, did not simply override law and practice in the South, as was undoubtedly intended, but also worked a radical change in the law in every northern state. See CHARLES FaIRMAN, RECONSTRUCTION AND REUNION, 1864-68, at 1117-1260 (1971) (Vol. VI of Oliver Wendell Holmes Devise History of the Supreme Court (Paul A. Freund ed.)); Gerhard Casper, Jones v. Mayer: Clio. Bemused and Confused Muse, 1968 SUP. CT. REV. 89, 100. To my mind, the lack of legislative concern with the impact of the statute in the North is a very big dog that did not bark. Cf. Sir Arthur Conan Doyle. Silver Blaze, in 1 THE COMPLETE SHERLOCK HOLMES 335, 349 (1930) (" [A] dog was kept in the stables, and yet, though someone had been in and had fetched out a horse, he had not barked enough to arouse the two lads in the loft.").

38. See, e.g., Fay v. Noia, 372 U.S. 391, 399-415 (1963) (insisting that claims defaulted in state court by failure to comply with valid state procedures not only should be, but always had been, open to federal habeas review). The powerful functional reasons to adopt the rule in Fay were not explained until Justice Brennan's dissent in Wainwright v. Sykes, 433 U.S. 72,99 (1977). Several commentators have criticized Fay's interpretation of legislative history. See Henry J. Friendly, Is Innocence Irrelevant? Collateral Attack on Criminal Judgments, 38 U. CHI. L. REv. 142,170-71 (1971) (concluding, "with as close to certainty as can ever be expected," that Fay's history is "simply wrong"); Lewis Mayers, The Habeas Corpus Act of 1867: The Supreme Court as Legal Historian, 33 U. CHI. L. REv. 31, 58 (1965) (concluding that Fay's history is "without historical foundation"); Dallin H. Oaks, Legal History in the High Court-Habeas Corpus, 64 MiCH. L. REv. 451, 472 (1966) (describing Fay as a "regal patchwork of history that, on close examination, proves as embarrassingly illusory as the Emperor's new clothes"). 
three) in the freedoms of speech and press and another on problems of church and state. One need only catalogue the constitutional flashpoints of the 1990s to see how issues shift. As constitutional questions, abortion, affirmative action, capital punishment, sex discrimination, and homosexual rights are issues of one generation. ${ }^{39}$ A constitutional law casebook published in 1970 (much less 1870) would not have had a single main case on any of these topics. ${ }^{40}$ Whatever may have been expected by the Framers, or desired by those who idealize them, the constitutional agenda is constantly changing.

It is a premise of my argument that constitutional change is right and necessary. That is not to say that change is always good or that we should be indifferent to its direction. Some constitutional reformations will come to seem unwise, and many others are probably unneeded. Moreover, the pace of change is an issue apart from its content. Many who agree that constitutional innovation is right and necessary also believe that it is sometimes rash. My endorsement of constitutional change does not reflect a taste for it. Indeed, I suspect that I am more grudging in that regard than most readers of this Essay. But it reflects a conviction that the capacity of constitutional doctrine to adapt to evolving economic, political, and social conditions is a great strength. New technologies continually remake our society, and, today, technological innovations seem to come with gathering speed. The capacity of constitutional law to avoid ossification and irrelevance in the face of accelerating changes in the society at large seems to me hugely valuable. Indeed, it is hard to imagine what our Constitution would be if original understandings had been faithfully maintained without "translation" to changed circumstances. ${ }^{41}$ Most likely, we would have had a succession of increasingly prolix organic documents, as heavily amended prior versions became too cumbersome or outdated. Ironically, the reason that we still have some version of the original Constitution and that we can refer (more or less meaningfully) to the intent of the Framers is the document's capacity for internal growth.

39. See John C. Jeffries, Jr., Lewis F. Powell, Jr. and the An of Judicial Selection, 112 HARV. L. REV. 597, 597-98 (1999) (noting that the issues that dominated Justice Powell's 16 years on the Supreme Court were not anticipated at the time of his confirmation).

40. See, e.g., Gerald GUNTHER \& NOEL T. DOwling. Cases and Materials on CONSTITUTIONAL LAW (8th ed. 1970) (providing no coverage of any of these issues except capital punishment, which is discussed in a brief series of notes at 922-23).

41. See Lawrence Lessig, Fidelity in Translation, 71 TEX. L. REV. 1165 (1993) (exploring a model of fidelity as translation to accommodate changes in context); Lawnence Lessig, Understanding Changed Readings: Fidelity and Theory, 47 STAN. L. REV. 395 (1995) (cxploring the pragmatic response of judges to changes in "interpretive context" as a justification for constitutional change). 
Notwithstanding the modern revival of interest in original intent, ${ }^{42} I$ doubt that acceptance of constitutional innovation is all that controversial. Perhaps it is only a failure of imagination, hut I cannot conceive of going back to the days when school segregation was not unconstitutional, ${ }^{43}$ and I doubt that many others wish to do so. Nor would we care to contemplate how much longer segregation might have lasted if three-fourths of the states had been required to agree to its demise. Candor requires me to say, however, that those who seriously believe that constitutional law should be fixed by the specific understandings of 1787 or 1866 (as distinct from the abstract generalizations that perpetually invite new wine to be poured into old bottles) should read no further. This article is grounded in a belief in both the inevitability and the desirability of constitutional evolution. Those who do not share the premise will necessarily find the argument unappealing.

\section{A. The Cost of Change}

For those who accept the desirability of constitutional change, the rightremedy gap has a silver lining. Put simply, the limitations on money damages for constitutional violations facilitate constitutional change. The doctrines that deny full individual remediation reduce the cost of innovation, thereby advancing the growth and development of constitutional law. If constitutional tort doctrine were reformed to assure full remediation, the costs of compensation would constrict the future of constitutional law.

The potential antagonism between retrospective remedy and future right is most clearly visible when the break from the past is sudden, dramatic, and undisguised by pretensions of continuity. Miranda $v$. Arizona ${ }^{44}$ is an example. In all likelihood, the Supreme Court would never have required Miranda warnings if doing so meant that every confessed criminal then in custody had to be set free. The decision in Miranda depended, I think crucially, on the (now abandoned) doctrine of nonretroactivity, which allowed the Court to give effect to new

42. See generally ROBERT H. BORK, THE TEMPTING OF AMERICA: THE POLITICAL SEduction OF THE LAW (1990); ANTONIN SCALIA, A MATTER OF INTERPRETATTON: Federal COURTS AND THE LAW (1997). For a historiography of constitutional originalism. see Barry Friedman \& Scott B. Smith, The Sedimentary Constitution, 147 U. PA. L. REV. 1, 9-33 (1999).

43. See Alexander M. Bickel, The Original Understanding and the Segregation Decision. 69 HARV. L. REV. 1 (1955) (concluding that the Fourteenth Amendment was not meant to condemn segregation). For more recent debate on whether Brown is consistent with the original understanding of the Fourteenth Amendment, compare Michael W. McConnell. Originalism and the Desegregation Decisions, 81 VA. L. REV. 947 (1995), which argues in the affirmative, with Michael J. Klarman, Brown, Originalism, and Constitutional Theory: A Response to Professor Mc Connell, 81 VA. L. REV. 1881 (1995).

44. 384 U.S. 436 (1966). 
requirements only in future applications. ${ }^{\text {ts }}$ As Justice Harlan recognized, nonretroactivity facilitated "long overdue reforms, which otherwise could not be practicably effected." 46 Harlan opposed nonincremental reform and partly for that reason opposed nonretroactivity, but he saw clearly the relation between them. Without innovation, there would be no need for nonretroactivity, and without nonretroactivity, there would be much less innovation. ${ }^{47}$

A similar relationship exists between constitutional innovation and money damages. In a world of constitutional stasis (real or imagined), there would be no constitutional argument against closing the right-remedy gap by making compensatory damages routine. Of course, there would still be the fear that strict liability might inhibit government from legitimate activities that are too hard to segregate, ex ante, from constitutional violations. Where constitutional standards are irreducibly indeterminate in application, ${ }^{48}$ the threat of strict liability might depress the activity level of government to an unacceptable degree. Presumably, this nonconstitutional cost would have to be offset against the benefit of increased enforcement of constitutional rights, but constitutional concerns would lie entirely on one side of the calculus. Within the realm of constitutional discourse, curtailment of money damages would be an unqualified loss.

In a world of change, however, constitutional concerns lie on both sides. On the one hand, strict liability would reduce the incidence of constitutional violations. On the other hand, it would risk the ossification of constitutional law by raising the cost of innovation. The current regime of fault-based liability for constitutional violations has the opposite vices and virtues. Qualified immunity reduces government's incentives to avoid constitutional violations. At the same time, it allows courts to embrace

45. See, e.g., Stovall v. Denno, 388 U.S. 293 (1967) (discussing the nonretroactivity of the identification evidence rule of United States $v$. Wade, 388 U.S. 218 (1967), and Gilbert $v$. California, 388 U.S. 263 (1967)); Linkletter v. Walker, 381 U.S. 618 (1965) (discussing the nonretroactivity of the exclusionary rule of Mapp v. Ohio, 367 U.S. 643 (1961)).

46. Mackey v. United States, 401 U.S. 667. 676 (1971) (Harlan, J., concurring in part and dissenting in part) (quoting Jenkins v. Delaware, 395 U.S. 213, 218 (1969)).

47. Current doctrine accords full retroactive application to new rulings in all cases pending at trial or on direct review, but habeas corpus has been changed to limit retroactive implementation of new rulings on collateral review. See Teague v. Lane, 489 U.S. 288, 300 (1989) (disapproving the Warren Court doctrine of nonretroactivity and requiring that a new rule applied to the defendant in the case at hand be "applied retroactively to all who are similarly situated" ): see also 28 U.S.C.A. \$ 2254(d)(1) (West Supp. 1998) (denying habeas review of claims resolved on the merits in state court unless the adjudication "resulted in a decision that was contrary to, or involved an unreasonable application of, clearly established Federal law, as determined by the Supreme Court of the United States"). On the relation between the Warren Court doctrine of nonretroactivity and the qualified immunity defense in constitutional damage actions, see infra text accompanying note 74 .

48. See Jeffries, supra note 14 , at $77-78$ (noting that the problem of unintended deterrence of legitimate government activities would be manageable if constitutional law were "precise and rule-like"). 
innovation without the potentially paralyzing cost of full remediation for past practice.

I know of no way to measure these competing values nor of any categorical basis for choosing between them, but the history of desegregation suggests the complexity of the problem. Brown v. Board of Education ${ }^{49}$ was one of three companion cases seeking injunctive relief against entities or officials of local government. ${ }^{50}$ At the time, $\S 1983$ damage actions had not yet been rediscovered,$^{51}$ nor had the modern class action evolved to permit "mass tort" litigation. ${ }^{52}$ Consequently, no one thought to sue for money damages. ${ }^{53}$ If such claims were brought today, they would fall within the limited class of cases in which current doctrine imposes strict enterprise liability. Specifically, Monell v. New York City Department of Social Services ${ }^{54}$ authorizes damages actions against local governments for acts committed pursuant to official policy or custom; and Owen v. City of Independence ${ }^{55}$ declares that in such cases, there is no defense of qualified immunity. School desegregation litigation meets these conditions. Since education is primarily a service of local government, desegregation suits typically are brought against local school boards and officials. The de jure segregation of which they complain, whether explicitly required by statute or inferred from local practice, would unmistakably qualify as a policy or custom. Indeed, it could scarcely be otherwise, as de jure segregation cannot arise accidentally or individually, but rather requires the kind of systemic and sustained practice that would satisfy even the narrowest conception of official policy. ${ }^{56}$

49. 347 U.S. 483 (1954). For the history of Brown, see RICHARD KLUGER, SIMPLE JUSTICE: THE History OF BROWN V. BOARD OF EDUCATION AND BLACK AMERICA'S STRUGGLE FOR EQUALITY (1976); and Michael J. Klarman, Brown, Racial Change, and the Civil Rights Movement, 80 VA. L. REV. 7 (1994).

50. The other two cases were Briggs v. Elliott, 132 F. Supp. 776 (E.D.S.C. 1955), involving an action brought against school officials of Clarendon County, South Carolina; and Davis v. County School Board, 103 F. Supp. 337 (E.D. Va. 1952). Another companion case, Gebhart $v$. Belton, 347 U.S. 483 (1954), involved an action against state school officials in Delaware. On the same day, the Court decided Bolling v. Sharpe, 347 U.S. 497 (1954), which struck down school segregation in the District of Columbia under the Due Process Clause of the Fifth Amendment.

51. See Monroe v. Pape, 365 U.S. 167, 187 (1961) (holding that the City of Chicago was not liable for a Fourth Amendment violation by city police officers because $\$ 1983$ did not extend to municipal governments).

52. See Peter H. Schuck, Mass Torts: An Institutional Evolutionist Perspective, 80 CORNELL L. REV. 941, 945 (1995) (noting that the term "mass tort" was not yet coined as late as 1969).

53. In the nature of things, there is no direct evidence of what no one considered. Indirect evidence comes from MARK V. TUSHNET, THE NAACP'S LEGAL STRATEGY AGAINST SEGREGATED EDUCATION, 1925-1950, at 148-49 (1987), which discusses the NAACP's effort to find desegregation plaintiffs who would settle for ideological incentives, because the material incentives were so slight.

54. 436 U.S. $658,690-91$ (1978).

55. 445 U.S. 622,638 (1980).

56. See, e.g., Pembaur v. City of Cincinnati, 475 U.S. 469, 500 (1986) (Powell, J., dissenting) (advocating a narrow reading that would limit official policy to rules of general applicability). 
In a hypothetical world in which current doctrine existed at the time of Brown, desegregation suits could have been brought as class actions seeking not only injunctive relief, but also money damages. The good-faith belief of officials in the pre-Brown validity of separate-but-equal-or indeed of any other outdated position-would have been no defense. Statutes of limitations would have barred plaintiffs from recovering reparations for all past wrongs, but a fair valuation of the injuries currently caused by racial apartheid, not to mention the gross underfunding of black schools, would have been astronomically high. While it may seem implausible to think that hundreds of billions of dollars in damages would actually have been extracted from local school districts and paid to their black students, such results would have followed from strict enterprise liability for constitutional violations. The challenge is to imagine what the world might have looked like had that regime been in place throughout the desegregation era.

Start with Brown itself. Might Brown have come out differently if the decision had come with a huge pricetag? In truth, it is hard to imagine Brown being decided differently, no matter what the cost. In our contemporary constitutional culture, both the correctness of the Brown decision and its necessity are axiomatic. Yet historians tell us that the Justices at the time struggled with the question, delayed the decision, and required luck and leadership to overcome internal opposition and dissent. ${ }^{57}$ Might the prospect of crippling judgments and school district bankruptcies have altered the terms of the debate? Or delayed the decision even further? Or stiffened the resolve of the initial dissenters to have their say in public? ${ }^{58}$ And what about the reaction to Brown, especially in the South, where some communities actually shut down their public schools altogether rather than

57. See KLUGER, supra note 49, at 582-616, 679-99. On the intemal debate among the Justices on Brown, compare MARK V. TUSHNET, MAKING CIVIL RIGHTS LAW: ThuRGOOD MARSHALL AND THE SUPREME COURT, 1956-1961, at 187-95 (1994), which argues that the Justices were simply "talking through their concems about what they knew they were going to do," with Michael J. Klarman, Civil Rights Law: Who Made It and How Much Did It Matter?, 83 GEO. LJJ. 433, 436-46 (1994), which argues that the Justices were genuinely divided during their conference deliberations on Brown.

58. Both in 1952 and after reargument in 1953, Justices Reed and Jackson initially favored sustaining Plessy v. Ferguson, 163 U.S. 537 (1896). See KLUGER, supra note 49, at 613, 682-83. Later Justice Jackson drafted a concurrence that showed substantial sympathy for white southemers, who had "built their segregated institutions for many years on an almost universal understanding that segregation is not constitutionally forbidden." Jackson Draft Opinion for Brown v. Board of Education 2 (Mar. 15, 1954) (available in the Library of Congress, Jackson Papers, Box 184, Case File: Segregation Cases). Elsewhere Jackson asked. “Can we honestly say that the states which have maintained segregated schools have not, until today. been justified in understanding their practice to be constitutional?" Id. at 5 . If Justice Jackson was uncomfortable invalidating a regime that the South had reasonably believed to be constitutional, how much more uncomfortable would he have been at the thought of massive damages liability for having maintained that regime? 
seat white children and black children in the same classroom $?^{59}$ Would the South have been less or more intransigent if the decision had come with crippling financial exposure? Of course, assessing how strict damages liability would have changed Brown is ultimately a matter of conjecture, but it seems likely that the prospect of money damages would have had some impact and that it would not have been good.

Brown, however, is the weakest example for this argument. The confidence that desegregation would somehow have emerged unscathed even from the more difficult environment of strict liability for constitutional torts begins to fade as one moves from Brown to subsequent decisions. Almost as important as Brown in practical effect, though not in symbolic salience, was Green v. County School Board, ${ }^{60}$ in which the Supreme Court lost patience and required the South to desegregate "now." transformed the constitutional obligation. Most courts had thought it a sufficient response to Brown that the government stop requiring separation by race. So-called "freedom of choice" plans, if fairly implemented, directly answered Brown's finding that segregation violated the Constitution if, and only if, required by law. ${ }^{62}$ In Green, however, the Court charged formerly de jure school districts with the "affirmative duty" to undo the effects of prior practice and achieve a "unitary" school system without racially identifiable schools. ${ }^{63}$ In essence, Green demanded the elimination of de facto segregation in districts with a de jure past.

Green was absolutely necessary if school desegregation was to become a living reality. In the words of Derrick Bell, Green was "as important a victory as was Brown." ${ }^{64}$ But no matter how essential Green appears in retrospect, the decision was not logically compelled. On a formal, doctrinal level, it would have been entirely consistent with Brown for the Court to have stopped with "freedom of choice." That the Court did not stop, but

59. See RobBins L. GATES, THE MAKING OF MASSIVE Resistance: VIRGINIA'S POlitics of Public SChool Desegregation, 1954-1956, at 128 (1962); J. Harvie Wilkinson III. HARRY BYRD AND THE CHANGING FACE OF VIRGINIA POLITICS, 1945-1966, at 138 (1968).

60. 391 U.S. 430 (1968).

61. Id. at 439.

62. For example, Judge Parker explained "freedom of choice" as follows: "The Constitution ... does not require integration. It merely forbids discrimination. It does not forbid such segregation as occurs as the result of voluntary action. It merely forbids the use of governmental power to enforce segregation." Briggs v. Elliott, 132 F. Supp. 776, 777 (E.D.S.C. 1955); see also Singleton v. Jackson Mun. Separate Sch. Dist., 355 F.2d 865, 871 (5th Cir. 1966) (following the same reasoning). See generally J. HARVIE WILKINSON III. From BROWN TO BAKKE: THE SUPREME COURT AND SCHOOL INTEGRATION: 1954-1978, at 108-11 (1979).

63. Green, 391 U.S. at 437-38.

64. Derrick A. Bell, JR., RaCe, Racism, and American law 385 (2d ed. 1980). For confirmation of this conclusion from a different perspective, see LiNO A. GRAGLIA. DISASTER BY DECREE: THE SUPREME COURT DECISIONS ON RACE AND THE SCHOOLS 67 (1976) (stating that Green "worked a revolution in the law of school segregation comparable to, indeed more drastic than, that effected by Brown"). 
insisted that segregation be eliminated "root and branch," ${ }^{65}$ may have depended upon the fact that doing so did not trigger a new round of massive damages liability. Who knows what the Court would have done if announcing an "affirmative duty" to eliminate racially identifiable schools had meant huge damages judgments against Southern school districts? Would the Justices have been willing to impose such liability on districts that had complied, albeit grudgingly, with existing court orders? There is no way to be sure, but it seems entirely plausible that Green might have come out differently under a regime of strict liability in money damages.

Similar arguments can be made about a succession of steps in the school desegregation saga. Perhaps most notable are the decisions finding de jure segregation outside the South. Colorado, for example, had prohibited racial segregation in accommodations since before Plessy $v$. Ferguson $^{66}$ and had maintained since statehood a constitutional ban against segregated schools. ${ }^{67}$ In the years following World War Il, the Denver School Board nevertheless acted to protect schools in an historically white neighborhood against black encroachment. New schools were constructed to accommodate black expansion, and attendance zones were drawn to keep older schools white. When it became plain that such actions constituted de jure segregation, the city tried to limit forced busing to the area in which the manipulations had occurred. The Supreme Court, however, ruled that intentional segregation in any significant part of a school district presumptively involved the whole. ${ }^{68}$ Therefore, the entire city of Denver became subject to court-ordered school desegregation, despite its generally good history.

Similarly aggressive findings of de jure segregation brought busing to cities throughout the North and West. In most of these cases, the courts could have leaned one way or the other, toward confining constitutional violations to the region of educational apartheid or toward expanding courtordered desegregation to the nation as a whole. The courts' general adherence to the expansive approach was facilitated by the decoupling of constitutional violations and money damages. If findings of de jure segregation had triggered massive damages actions against Northern school districts, the decisions might well have come out differently. ${ }^{69}$

65. Green, 391 U.S. at 438.

66. 163 U.S. 537 (1896).

67. See COLO. CONST. art. IX, $\S 8$ (“" [N]or shall any distinction or classification of pupils be made on account of race or color.").

68. See Keyes v. School Dist. No. 1, 413 U.S. 189, 203 (1973).

69. Note that the costs to the government of damage awards for past misconduct and of injunctive relief against future misconduct are additive, not altemative. This is not only because a court that has awarded damages would be willing, if repetition were threatened, to issue injunctive relief, though that possibility seems overwhelmingly likely; it is also because the damage judgment itself carries the threat of future damage judgments if the misconduct is repeated. Thus, 
Of course, it is also true that strict damages liability would encourage greater compliance with existing constitutional requirements, whatever they may be at the time. To be more precise, strict enterprise liability would force government to "internalize" the cost of all constitutional violations, including not only those that would have been prevented by cost-justified precautions, but also those that would not have been. ${ }^{70}$ The size of the latter category depends importantly on the clarity of constitutional norms. In the language of torts, to the extent that the constitutional mandate is clear and rule-like, cost-justified precautions should eliminate violations. To put the same point in terms of the doctrine of $\S 1983$, to the extent that the constitutional mandate is clear and rule-like, the defense of qualified immunity will not matter. A reasonable officer could not believe lawful any act that violates a specific and plainly applicable constitutional rule. For such cases, negligence and strict liability amount to the same thing. But to the extent that the constitutional norm is an indeterminate standard, no costjustified precaution may succeed in differentiating ex ante legitimate acts of government from constitutional violations. It is in these cases that strict liability would matter, by forcing the government to bear all losses and to spread them among citizens generally. The result would be a shift in activity level, as the government reduced activities that could not efficiently be segregated, ex ante, from constitutional violations. ${ }^{71}$ In consequence, there would be fewer constitutional violations and greater compliance with constitutional norms.

In itself, the reduction in constitutional violations is an unqualified good, and it is precisely this benefit that the advocates of strict enterprise liability for constitutional torts seek to gain. ${ }^{72}$ Of course, one would still

the cost of future compliance must be borne in any event, whether or not the government also bears the cost of retrospective compensation.

70. When administration is completely predictable, a negligence standard (such as that created by the law of qualified immunity) will induce government to take all cost-justified precautions. The real bite of strict liability, therefore, concerns those violations that cannot efficiently be prevented by such precautions. See KENNETH S. ABRAHAM, THE FORMS AND FUNCTIONS OF TORT LAW 159-61 (1997).

71. To put this point into a practical context, one need only imagine a supervisor instructing police officers (as all police are instructed these days) on the law of the Fourth Amendment. Under the regime of qualified immunity, the instructor would explain the rules of search and seizure and enjoin adherence to them, but would also tell the officers that reasonable mistakes would not be held against them. Now imagine the same situation under a regime of strict liability. The supervisor would instruct her charges not only to be careful about probable cause but also, and more importantly, not to search in any doubtful case. Under strict liability, the supervisor would require a kind of super-probable cause, steering well clear of the constitutional standard in order to avoid liability for inevitable mistakes. In consequence, there would be fewer searches.

Jeffries, supra note 14, at 73-74 (footnotes omitted).

72. See, e.g., Mark R. Brown, The Failure of Fault Under \$1983: Municipal Liability for State Law Enforcement, 84 CORNELL L. REv. 1503, 1504-05 (1999) (criticizing Jeffrics, supra note 14). 
have to weigh the value of increased constitutional compliance against the costs of decreased activity levels for the legitimate business of government. But more importantly, the gain in compliance with current requirements would also have to be balanced against the potential for inhibiting the growth and development of constitutional law. Consequently, the merits of strict liability for constitutional violations depend significantly on one's attitude toward change. Holding governments absolutely liable in money damages for all constitutional violations is more readily supported if one assumes (or desires) constitutional stasis, while introducing some requirement of fault into damages actions is more readily supported if one assumes (or desires) constitutional innovation. Under either view, it is important to recognize the potential antagonism between past remedy and future right.

\section{B. Constitutional Redistribution}

The curtailment of money damages for constitutional violations has a related consequence, less apparent but more important. The requirement of fault for awarding money damages builds into the structure of constitutional remedies a bias in favor of the future. Basically, the limitation on retrospective relief, together with the modern availability of injunctive and declaratory relief, continually shifts societal resources from the past to the future. Older claimants are disadvantaged by doctrines that deny full individual remediation for past injuries; younger ones are advantaged by the continuing evolution of constitutional law to meet new challenges. Even though the rhetoric of constitutional rights is often absolutist, societal resources remain finite. Commitment of resources in one area implies curtailment in another. Limiting damages liability to cases of fault facilitates constitutional innovation by allowing courts to disregard the past injuries caused by conduct now seen as unacceptable. In general, flexibility and innovation disproportionately benefit younger generations. The result is a rolling reallocation of constitutional resources from older to younger citizens. In this way, the structure of constitutional remedies is systemically biased in favor of the future.

It is important to note that this argument does not depend on a simplistic equation of damages with the past or injunctions with the future. Both damages and injunctions have past and future aspects. Damages are retrospective remedies for past wrongs, but the prospect of damages liability encourages future compliance with legal norms. Injunctions are prospective remedies against future wrongs, but they are enforced by 
retrospective penalties for past failure to comply. With both remedies, punishment for past violations promotes future compliance. ${ }^{73}$

It follows that at any given moment in time, there would be no real connection between damages and "the past" nor between injunctions and "the future." Under conditions of stasis, the choice of remedy would have no distributive consequence. The claim that the current fault-based regime of money damages biases constitutional remedies in favor of the future depends on constitutional change. The more one sees (or desires) constitutional movement, the more important it is to facilitate change by reducing the cost of innovation and the greater the future-oriented redistribution of resources that is accomplished by the limitation on money damages.

In essence, the requirement of fault in constitutional tort law functions as a remedy-specific variant of nonretroactivity, applicable only to actions for money damages. ${ }^{74}$ In that respect, it is unlike Warren Court nonretroactivity, which was articulated in terms of rights and barred retroactive application in all remedial contexts. Moreover, nonretroactivity applied only to a handful of rulings that marked a clean break with prior law. Qualified immunity, by contrast, extends as well to the smaller, evolutionary changes that characterize adjudication generally, though it bars only money damages. The result is a systematic unwillingness to compensate those who were injured prior to a decision clarifying or specifying a legal rule and a consequent redirection of energy and resources to those who are injured after that date. This tilt in the structure of constitutional remedies biases the system against past claimants and in favor of future claimants. It redistributes societal resources as it encourages constitutional change.

Focusing on the distributive consequences of constitutional remedies begins to make sense of a line of cases that has left many scholars puzzled, if not appalled. Edelman v. Jordan ${ }^{75}$ limited the fiction of Ex parte Young ${ }^{76}$ to suits for prospective relief, thus barring retrospective relief against states as such, at least absent explicit congressional override. To Akhil Amar, the prospective-retrospective distinction reflects an "obvious lack of principle" 77 and creates an "ad hoc mishmash of Young and Edelman, of full remedy and state sovereignty, of supremacy and immunity, of law and

73. See OWEN M. FISS, THE CIVIL RIGHTS INJUNCTION 9-12 (1978).

74. See Fallon \& Meltzer, supra note 4, at 1795-96.

75. 415 U.S. 651,678 (1974).

76. 209 U.S. 123, 159 (1908) (allowing state officers who violate federal rights in the exercise of official duties to be sued on the ground that they are not acting in their official capacities).

77. Amar, supra note 2, at 1479. 
lawlessness." 78 The Edelman Court justified the "lawlessness" of denying retrospective relief chiefly in terms of precedent. To the extent that it attempted a functional explanation, the Court pointed to the impact on state treasuries, but admitted that "the difference between the type of relief barred by the Eleventh Amendment and that permitted under Ex parte Young will not in many instances be that between day and night." 79 Prospective relief under Ex parte Young also costs money, often lots of it, and the dollars expended will not have any less impact on state treasuries just because they fund prospective relief.

It is true, of course, that prospective relief plus retrospective relief will always cost more than prospective relief alone. To that extent, the Edelman Court had a practical argument. It does not follow, however, that the Court should categorically distinguish prospective and retrospective remedies. Some prospective remedies are very costly, while others are not. Some retrospective remedies are very costly, while others are not. If cost itself were the only concern, it might make more sense to bar very expensive remedies, of whatever sort, than to allow prospective and to prohibit retrospective remedies, of whatever magnitude.

The fragility of Edelman's reasoning was etched in sharp relief by the decision three years later in Milliken v. Bradley (Milliken II). ${ }^{80}$ There the Court upheld a desegregation decree ordering the expenditure of state funds for remedial reading programs in predominantly black schools. In later years, such court-ordered educational "sweeteners" became increasingly salient in the desegregation landscape, most famously in a series of orders requiring expenditures of approximately $\$ 1.5$ billion by the State of Missouri on behalf of the Kansas City school system. ${ }^{81}$ It is hard to believe that the retrospective relief denied in Edelman would have reached anything like that sum. At the very least, interpreting the Eleventh Amendment to allow prospective relief of that magnitude, while barring all retrospective remedies, suggests that the line between the two cannot be explained simply by reference to the impact on state treasuries.

The prospective-retrospective distinction can be explained, however, as a way of avoiding constitutional ossification and encouraging generational

78. Id at 1480; see also Jackson, supra note 30 , at 88 (noting the " much criticized distinction drawn in Edelman v. Jordan" and citing sources).

79. Edelman, 415 U.S. at 667.

80. 433 U.S. 267, 290 (1977) (relying on the fact that the ordered remedies were "prospective," even though they were also, like the remedies rijected in Edelman, "compensatory"). See generally Carlos Manuel Vázquez, Night and Day: Cocur d'Alene, Breard. and the Unraveling of the Prospective-Retrospective Distinction in Eleventh Amtendment Doctrine, 87 GEO. L.J. 1 (1998) (exploring unstable characterization in subsequent cases and calling for a retum to the original Edelman understanding that the Eleventh Amendment barred only retroactive monetary relief against states).

81. See Missouri v. Jenkins, 515 U.S. 70, 77-79 (1995) (describing expenditures that collectively approximate that figure). 
wealth transfer. Start with Edelman or, rather, with the general proposition for which the case has come to stand. Edelman itself is highly atypical, for it was a rare instance in which the Court found a damages action against a state officer barred by the Eleventh Amendment. ${ }^{82}$ Ordinarily, damages are available from state officers (and indirectly from the state itself), if the plaintiff can defeat qualified immunity. Why the Edelman Court rejected this evasion is not clear, but it probably flowed from the fact that the plaintiff's claim sounded in contract rather than tort. Traditional agency rules make a servant liable for a tort committed in the master's business but not for breach of the master's contract. ${ }^{83}$ Agency law may have encouraged the Court to see Edelman as a case in which officer liability would not lie. Or perhaps the Court simply wanted to make a point about the continued importance of the Eleventh Amendment as a (largely symbolic) structure of federalism. $^{84}$

For present purposes, the crucial point is that Edelman's preclusion of an officer suit is very much the exception rather than the rule. In general, constitutional tort actions against state officers for manifestly official misconduct are routinely allowed, so long as they are properly pleaded as suits against the officer in his or her "personal" capacity. ${ }^{85}$ In practice, therefore, retrospective remedies are available against state officers (and indirectly against the states that employ them) in which the officer could not reasonably have believed the act to be lawful. ${ }^{86}$ Thus, the denial of a

82. The dominant position is reflected in such cases as Scheuer v. Rhodes, 416 U.S. 232 (1974), which upheld damage actions "seeking to impose individual and personal liability on the named defendants" for their official misconduct. Id. at 238.

83. See JOSEPH STORY, COMMENTARIES ON THE LAW OF AGENCY $\$ 302$, at $375-76$ (5th ed., Boston, Little, Brown 1857) (noting that officers are not personally liable for breach of contract): Louis L. Jaffe, Suits Against Governments and Officers: Sovereign Immunity, 77 HARV. L. REV. 1, 28-29 (1963) (distinguishing trespass, where officer suits are allowed despite sovereign immunity, from contract, where the sovereign's consent to be sued is usually required); see also Jeffries, supra note 14, at 67 (noting that the alternative of an officer suit is more frequently barred in statutory cases, where "the underlying claim looks more like contract than tort"); Woolhandler, supra note 22 , at 428 (suggesting that the liability of an agent for the acts of the master approximates, rather than exactly tracks, the distinction between contract and tort).

84. This interpretation would bring Edelman into alignment with Seminole Tribe v. Florida, 517 U.S. 44, 73-76 (1996), in which the Court strained to confront an Eleventh Amendment issuc that arose only by virtue of an extremely odd and apparently fact-specific evasion of Ex parte Young. See Jeffries, supra note 14, at $51 \mathrm{n} .19$ (characterizing the Seminole Tribe Court's insistence that Congress intended to preclude officer suits under Ex parte Young as "willfully perverse"); Daniel J. Meltzer, The Seminole Decision and State Sovereign Immunity, 1996 SuP. CT. REV. 1, 43 (describing the same point as "singularly unpersuasive"). For the possible implications of a broader reading of Seminole Tribe, see Vicki C. Jackson, Seminole Tribe, the Eleventh Amendment, and the Potential Evisceration of Ex parte Young, 72 N.Y.U. L. REV. 495 (1997).

85. See, e.g., Hafer v. Melo, 502 U.S. 21, 27-28 (1991) (holding that a suit against a state auditor for employment decisions she made only because of that office was nevertheless properly a suit against the officer in her "personal" capacity).

86. See Hunter v. Bryant, 502 U.S. 224, 228 (1991) (noting that an officer would be immune from liability for an unconstitutional arrest "if a reasonable officer could have believed" there had been probable cause); Anderson v. Creighton, 483 U.S. 635, 639 (1987) (same). 
damages remedy does not extend to all constitutional violations, but rather is targeted to cases of constitutional uncertainty or innovation. It is precisely in these cases that the curtailment of money damages serves the useful purposes of avoiding excessive inhibition of the legitimate activities of government and reducing the costs of constitutional change.

Milliken II remedies can also cost a great deal and cannot readily be distinguished from money damages on that ground, but their systemic effects are very different. Milliken II educational "sweeteners" are really a form of structural injunction and as such are relentlessly forward-looking. The costs of such remedies may be high, but they are always lower than if they were accompanied by the award of money damages for past failures. In other words, courts facing the question of whether to order future relief no doubt take account of the costs of doing so, but they do not have to confront the additional cost of compensation for past harm. More importantly, the benefits of Milliken II remedies flow to current and future students, not their predecessors. The result is a rolling redistribution of resources toward younger citizens, who have an expectation of longer participation in society and in whom society may legitimately take a greater interest.

Of equal importance is the fact that the benefits of Milliken II remedies are paid in kind, not in cash. Though past and future claimants may be similarly situated in terms of injury, the societal consequences and implications of remedying their injuries are therefore very different. For example, the investments in education ordered by Milliken II must be used for that purpose and cannot be converted, as cash payment necessarily could be, to a variety of other uses that the recipients might prefer. As a society, we might well prefer to spend additional funds to educate future students rather than distribute cash payments to poorly educated former students. From this perspective, Edelman and Milliken II do not create an "ad hoc mishmash" 87 of unprincipled contradiction but instead reflect a sensible (if unarticulated) policy of investing in the future.

Of course, in a hypothetical world in which infinite resources were available to redress any harm deemed constitutionally significant, there would be no need to choose between past and future beneficiaries and therefore no justification for preferring one group over the other. But despite the absolutist and originalist rhetoric of constitutional law, the world in which we live is one of finite resources, competing demands, evolving conditions, and changing priorities. In such a world, the question will often be not whether we should redress both past and future injuries, but whether we can redress injury at all. The subordination of past claimants (where the underlying right is unclear or changing) is both a

87. Amar, supra note 2 , at 1480. 
redistribution of constitutional wealth and, at least in some cases, a necessary precondition for adapting old doctrine to new challenges.

\section{THE RELEVANCE OF INJUNCTIONS}

The policies advanced here to support fault-based liability for money damages also undergird the modern law of structural reform injunctions. Generally speaking, prospective relief against future constitutional violations can be had without regard to fault (except insofar as the underlying right may require proof of a particular state of mind to make out the violation).$^{88}$ Conduct violative of the Constitution may be enjoined, even if the underlying right was unclear or newly declared and the officer had an eminently reasonable belief in the legality of the act in question. For injunctions, qualified immunity does not exist.

The short explanation for this rule is that the reasons for curtailing money damages do not obtain for injunctive relief. There is no grave danger that an injunction will deter the legitimate and socially desirable business of government, since the prohibition can be aimed quite specifically at the objectionable conduct, with ways of resolving uncertainty readily at hand. Nor do injunctions risk freezing the law. So long as damages liability for the discarded past practice is adequately constrained, injunctions can embrace innovations at no greater cost than they intrinsically require. Most importantly, injunctions promote reforms, not reparations. They direct societal resources toward investments in future growth and development, not toward cash outlays for past harms. All of which is merely to repeat that justifications for having a fault requirement in actions for money damages do not apply to suits for prospective relief. The law of injunctions is therefore a natural boundary for the defense of qualified immunity.

There is also a deeper and more interesting relationship between the fault-based standard for damages liability and the law governing structural reform injunctions. They are mirror images, doctrinally reversed reflections of the same underlying policies. While the defense of qualified immunity creates a shortfall between constitutional rights and the damages remedy, structural reform litigation expands injunctive remedies beyond constitutional rights. The fighting issue in structural reform cases is not whether a court should enjoin constitutional violations, but how far a court

88. A slight inroad on this proposition may have been made by ldaho $v$. Coeur d'Alene Tribe. 521 U.S. 261, 288-92 (1997) (O'Connor, J., concurring). Coeur d'Alene is not an easy case to understand, but it seems to have created a narrow exception to the availability of prospective relief under Ex parte Young. For analysis of this decision and its implications, see Vicki C. Jackson, Coeur d'Alene, Federal Courts and the Supremacy of Federal Law: The Competing Paradigms of Chief Justices Marshall and Rehnquist, 15 CONST. COMMENTARY 301, 309-18 (1998); and Vázquez, supra note 80, at 42-51. 
should go in regulating structures and practices that are not unconstitutional. The justification for such regulation is that certain structures and practices, though not in themselves unconstitutional, contribute to an environment of constitutional risk. To the extent that injunctive remedies address antecedent matters that are only strategically and probabilistically related to constitutional violations, they may be said to have gone beyond the underlying rights.

Fortunately, the phenomenon of remedies surpassing rights is well described in the literature on structural reform litigation and beautifully illustrated by specific examples from prison reform litigation. ${ }^{89}$ Federal courts historically followed a "hands-off" policy on prison administration, but close inspection of the appalling conditions in many of America's prisons led them to intervene. Responding, as they were, to overall conditions of brutality and degradation, the courts quite naturally considered the cumulative effect of conditions of confinement, not just specific acts or practices. Institutional arrangements not in themselves unconstitutional could be found so in light of the totality of the circumstances that defined the prison experience. Moreover, the remedies used to address the totality of the circumstances were not limited to the suppression of specific objectionable practices but also extended to antecedent institutional and structural arrangements that made constitutional violations likely to occur. In other words, courts increasingly focused on prophylactic precautions against the risk of constitutional violations. Over time, specific remedial strategies that recurred in one case after another assumed a life of their own. They underwent a subtle transformation from ad hoc remedies for independently demonstrated unconstitutionality of confinement to normative criteria for assessing the acceptability of prison operation. In effect, remedies became quasi-rights. ${ }^{90}$

89. For discussion of the phenomenon of remedies surpassing or redefining rights in structural reform cases, see PETER W. LOW \& JOHN C. JEFFRIES, JR., CIVIL RIGHTS ACTIONS: SECTION 1983 AND RELATED STATUTES 811 -14 (2d ed. 1994); William A. Fetcher. The Discretionary Constitution: Institutional Remedies and Judicial Legirimacy, 91 YALE LJ. 635. 683-88 (1982); Daryl J. Levinson, Rights Essentialism and Remedial Equilibration. 99 COLUM. L. REV. 857, 873-89 (1999); and Note, Complex Enforcement: Unconstitutional Prison Conditions, 94 HARV. L. REV. 626, 637-40 (1981). On the history of prison reform litigation. see MALCOLM M. FEELEY \& EDWARD L. RUBIN, JUDICIAL POLICY MAKING AND THE MODERN STATE: HOW THE COURTS REFORMED AMERICA'S PRISONS 27-145 (1998).

90. See Note, supra note 89 , at $638-39$. As the Note recognizes,

The tendency in complex enforcement is for remedies to become part of the substantive law, as "rights" in themselves or, more generally, as the normative criteria by which a system's lawfulness is judged. This transformation of remedies into norms has occurred through two developments.

First, complex remedies have tended to converge, with certain calcgories of affirmative requirements becoming more or less standard. ...

Second, as these affirmative requirements have become standard, they have ceased to be merely remedial responses to wrongs independently identified. Rather. 
Nowhere is this sort of transformation more evident than in the litigation on double-occupancy of prison cells originally designed to house a single inmate. Early cases ordered an end to double-celling as a way of addressing deplorable conditions of confinement resulting, in part, from overcrowding. ${ }^{91}$ Over time, one-inmate-per-cell became a standard feature of remedial injunctions and a widely accepted benchmark of correctional practice. ${ }^{92}$ Whether double-celling violated the Constitution and, if so, under what circumstances, were questions that almost got lost in the shuffle. The Supreme Court finally faced the issue in Rhodes $v$. Chapman, ${ }^{93}$ in which the lower courts had prohibited double-celling not in an otherwise appalling institution but in "unquestionably a top-flight, first-class facility." 94 In effect, the lower courts' ruling made double-celling per se unconstitutional. Faced with this right-remedy transformation, the Supreme Court balked, insisting that the overall conditions of confinement at the "top-flight, first-class facility" in question fell far short of the level of outrage that constitutes cruel and unusual punishment. Interestingly, the Court's holding action appears to have been at most a partial success, as a series of prison reform cases after Rhodes found prison overcrowding responsible for unconstitutional conditions of confinement in nine of eleven cases. ${ }^{95}$ Despite contrary signals from the Supreme Court, the clear and intelligible benchmark of one-inmate-per-cell continues to prevail. Whether this phenomenon is described as remedy exceeding right or as remedy implicitly redefining right ${ }^{96}$ or as remedy merely becoming a "criter[ion] by which .. lawfulness is judged" 97 is for present purposes immaterial. The important point is that in structural reform litigation, courts prospectively and selectively impose requirements that in other remedial contexts would not be constitutionally compelled.

In essence, there are two right-remedy gaps in constitutional law, and they run in opposite directions. In actions for money damages, remedies stop short of rights. In these cases, qualified immunity drives a wedge between right and remedy and defeats "full" remediation. In suits for structural reform injunctions, remedies exceed rights. In these cases, courts

they occupy an ambiguous status: while they are not constitutional rights as such, they Id. seem to represent the criteria of legality and therefore are more than mere remedies.

91. See Chapman v. Rhodes, 434 F. Supp. 1007,1019 (S.D. Ohio 1977) (citing prior cases), aff'd, 624 F.2d 1099 (6th Cir.), rev'd, 452 U.S. 337 (1980).

92. See id. at 1021 (citing expert sources in support of an order to end double-celling).

93. 452 U.S. 337 (1980).

94. Id. at 341 (quoting the district court opinion in Chapman, $434 \mathrm{~F}$. Supp. at 1009).

95. See James E. Robertson, When the Supreme Court Commands, Do the Lower Federal Courts Obey? The Impact of Rhodes v. Chapman on Correctional Litigation, 7 HAMLINE L. REv. 79, 90-93 (1984) (discussing prison overcrowding).

96. This is what my colleague Daryl Levinson has termed "remedial substantiation." See Levinson, supra note 89 , at 904.

97. Note, supra note 89 , at 638 . 
seek to prevent constitutional violations by regulating antecedent structures and practices that create the risk of such violations. In neither context is remedy perfectly aligned with right.

Nor should that fact be surprising. Just as there are strategic and pragmatic concerns incorporated into the definition of constitutional rights, ${ }^{98}$ there are also strategic and pragmatic concerns so tied to particular enforcement contexts that they are conveniently assigned to the law of remedies. To say that there are gaps between right and remedy is really only to acknowledge that the law of remedies, as a body of doctrine not generalizable across all enforcement mechanisms, exists.

The right-remedy gaps in constitutional torts and structural reform injunctions differ in conventional justification and in political constituency, but are closely aligned in functional consequence. The curtailment of money damages for constitutional violations in cases of unclear or evolving legal standards facilitates constitutional change. The cost of innovation is held down if new rules can be adopted without full compensation for the discarded past practice. Structural reform injunctions also facilitate constitutional change. They encourage experimentation, allow for trial and error, and give courts the time to work out the proper constitutional rules for complex institutions such as schools and prisons. They hold down the cost of innovation by allowing it to proceed piecemeal, without the potentially paralyzing requirements of premature generalization and categorical applicability.

The curtailment of money damages in cases of changing constitutional standards also shifts societal resources away from reparations and toward reforms. Qualified immunity disfavors the backward-looking remedy of cash payments to victims of past harms and, in so doing, opens the door to forward-looking remedies requiring investments in the future. Structural reform injunctions walk through that door. They direct resources toward preventing future harms rather than compensating past injuries, thereby implementing the bias in favor of the future that qualified immunity invites and allows.

In short, the gaps between right and remedy in constitutional tort actions and in structural reform litigation are doctrinally opposite but functionally synergistic. Together they build into the deep structure of American constitutionalism a healthy capacity for change and a redistributive bias in favor of the future.

98. See Levinson, supra note 89 , at $882-84$ (discussing one-person-one-vote as an area in which the kinds of pragmatic and institutional concerns traditionally relegated to the law of remedies influence the articulation of constitutional rights): David A. Strauss. The Ubiquiry of Prophylactic Rules, 55 U. CHI. L. REV. 190, 195 (1988) (arguing that prophylactic elements of constitutional rights are "the norm, not the exception"). 
Of course, these advantages are not secured without cost. Both rightremedy gaps have their critics, and the critics have much to say. Opponents of the fault requirement in constitutional tort law complain, with reason, that limiting money damages reduces the incentives for strict compliance with constitutional norms. Opponents of structural reform injunctions complain, also with reason, that judicial assumption of broad managerial authority over public institutions detracts from political accountability ${ }^{99}$ and risks arrogant overestimation of the efficacy of top-down reform. ${ }^{100}$

But just as we should identify the shortcomings of the current remedial regimes, we should also recognize their strengths. In particular, we should recognize that the fault requirement in constitutional torts, especially when coupled with the availability of structural reform injunctions, helps as well as hurts. In a world in which evolution and growth of constitutional doctrine are both expected and accepted, the construction of constitutional remedies to facilitate change and to encourage investment in the future is, at least partly, a good thing.

99. See, e.g., Paul J. Mishkin, Federal Courts as State Reformers, 35 WASH. \& LeE L. REv. 949, 965-66 (1978).

100. See, e.g., Gerald N. Rosenberg, The hollow hope: Can Courts Bring about SOCIAL CHANGE? (1991). 